\title{
Computers zijn niet nodig voor goed onderwijs in de geneeskunde*
}

\author{
J. van der Meer
}

Goed onderwijs in de geneeskunde moet goede dokters opleveren. Wat is een goede dokter? In elk geval een vaardige hulpverlener met kennis van zaken en een medemenselijke houding ten opzichte van de patiënt. De medische faculteiten sleutelen voortdurend aan hun curriculum om aan de ambitieuze eisen van het Raamplan 2002 artsopleiding te voldoen. Hoorcolleges zijn uit de tijd, en onderwijs in kleine groepen met een wetenschappelijk medewerker als procesbegeleider is de trend. Deze onderwijsvorm is arbeidsintensief en duur, zeker nu de studentenaantallen sterk toenemen. Computerondersteund onderwijs ('computer-assisted learning' (CAL)) lijkt dan een welkome oplossing. Vergeleken met klassieke onderwijsvormen zijn de resultaten daarvan veelbelovend. ${ }^{1}$ Het ontwikkelen van de computerprogramma's is weliswaar arbeidsintensief en kostbaar, maar daarna kan de begeleiding sterk worden beperkt. Waarom dan toch kritiek?

Natuurlijk is de computer een handig hulpmiddel voor de medisch student, zoals de hometrainer dat is voor de wielrenner. Anders dan de hometrainer heeft de computer evenwel ernstige bijwerkingen. In het onderwijs ligt de nadruk tegenwoordig niet meer op 'weten', maar op 'kunnen opzoeken'. Een goede dokter heeft evenwel een flinke hoeveelheid kennis nodig, waarvan een groot deel paraat moet zijn. Een arts die met een schuin oog voortdurend naar het beeldscherm moet kijken tijdens het contact met de patiënt, is ongeloofwaardig. Het is verder nooit bewezen dat CAL meer kennis oplevert dan studeren uit een leerboek, uittreksels maken en memoriseren.

Niemand wordt een goede wielrenner op een hometrainer. Niemand wordt een goede arts door CAL. Een ambitieuze wielrenner kan zoveel als hij wil in weer en wind trainen, maar de opleiding van de medisch student wordt door een voorgeschreven aantal studielasturen beperkt. Daardoor is het doen van avond- en nachtdiensten tijdens de coassistentschappen soms al niet meer verplicht. ${ }^{2}$ Medisch probleemoplossen wordt vooral in de praktijk geleerd en niet achter de computer. Faculteiten moeten dan ook meer investeren in de klinische fase.

Zal de pas afgestudeerde basisarts in 2020 dankbaar terugdenken aan het computerprogramma waarmee hij of zij destijds de multiplechoice-examenvragen over spoedeisende hulp beantwoord heeft? Met veel waardering herinnert zij zich wel de zaalassistent met wie zij haar eerste weekenddienst deed. De meester-gezelrelatie is lange tijd uit de mode geweest, maar wordt nu in een nieuwe jas gepresenteerd als 'cognitive apprenticeship': ${ }^{3}$ leren onder leiding van een ervaren arts. Daar is geen computer voor nodig.

Zonder computers heeft de geneeskunde in de afgelopen 50 jaar belangrijke vorderingen gemaakt. ${ }^{4} \mathrm{Er}$ is geen enkel bewijs dat computers nodig zijn om de goede dokters op te leiden die de komende

* Dit artikel verschijnt ook in het Nederlands Tijdschrift voor Geneeskunde. 
50 jaar voor verdere vooruitgang zullen zorgen.

\section{Literatuur}

1. Greenhalgh T. Computer assisted learning in undergraduate medical education. BMJ 2001;322:40-4.

2. Halma C. Leerzame nachten. Med Contact 2005; 60:1362-3.

3. Stegeman JE. Dokters als connaisseurs en leermeesters in het praktisch klinisch onderwijs: goed voorbeeld doet goed volgen. Ned Tijdschr Geneeskd 1997;141:47-51.

4. Mackenbach JP, Looman CWN, Kunst AE. De ontwikkeling van de sterfte aan aandoeningen die (gedeeltelijk) door medische zorg voorkoombaar of behandelbaar zijn geworden, 1950-1984. Ned Tijdschr Geneeskd 1988;132:1665-9.
De auteur:

Prof. dr. J. van der Meer is internist in ruste.

Correspondentieadres:

Prof. dr. J. van der Meer, De Wijde Blik 19, 1189 WJ

Amstelveen.

\section{Summary}

There is no convincing evidence that computer-assisted learning (CAL) leads to better doctors. Apprenticeships supervised by expert teachers are a time-honoured and effective way to educate future doctors. Medical faculties should not invest in CAL at the expense of properly supervised clerkships. (Van der Meer J. Computers do not improve undergraduate medical education. Dutch Journal of Medical Education 2006;25(2):98-99.) 